\title{
Multi-Criteria Decision Making-Based Comparison of Power Source Technologies for Utilization in Automobiles
}

\author{
Görkem F. Üçtuğ, Naz E. Kabakcı, O. Buğu Bekdikhan, and Betül Akyürek
}

\begin{abstract}
Four automobiles with different power sources were compared and ranked according to five different criteria by using a multi-criteria decision making approach named TOPSIS. An internal combustion engine vehicle, an electric vehicle, a hybrid electric vehicle and a hydrogen fuel cell vehicle, all with similar sizes and characteristics, were compared in terms of their initial costs, operating costs, environmental effects, on-board safety and performance. The scores for each of these criteria were obtained from the literature. Criteria weights were determined via a survey which was conducted to a total of 151 people, who were then divided into three groups according to their monthly income, considering that with variant incomes preferences and priorities differ. For all cases, the ideal technology emerged to be internal combustion engine vehicles, due to their low initial costs, external costs and high performance. Hybrid electric vehicles appeared almost as favorable as internal combustion engine automobiles. Hydrogen fuel cell vehicles gathered the least scores, given the premature state of the technology and consequent high prices. The results of our study show that while internal combustion engine vehicles continue to dominate the automotive market for the time being, hybrid electric vehicles have the potential to become competitive alternatives.
\end{abstract}

Index Terms-Electric vehicles, fuel cell vehicles, hybrid electric vehicles, internal combustion engine, multi-criteria decision making, TOPSIS.

\section{INTRODUCTION}

Currently, the energy demand of the transportation sector is predominantly met by oil, with the fuels obtained via processing of oil powering more than $90 \%$ of the entire sector. However, there are many concerns regarding the use of oil-based fuels. Some of these concerns are high costs, uncertainty of sustainable supply, greenhouse gas (GHG) emissions and emissions of air pollutants such as NOX, PM10 and volatile organic compounds [1]. As of 2012, transportation sector is responsible for almost $27 \%$ of the total energy consumption in the world and $33.7 \%$ of the entire GHG emissions [2].

Automobiles powered by electricity or hydrogen energy are being advocated in order to decrease the oil-dependence in the transportation sector [1], [3]. There are different ways to make use of electric energy or hydrogen energy in automobiles. Electric vehicles are solely powered by electricity whereas hybrid electric vehicles possess a more complex system involving an electric motor coupled with an

Manuscript received March 25, 2014; revised June 26, 2014.

The authors are with the Energy Systems Engineering Department, Bahcesehir University, Istanbul, Turkey (e-mail: görkem.uctug@bahcesehir.edu.tr, olcaybugu.bekdikhan@bahcesehir.edu.tr betul.akyurek@bahcesehir.edu.tr,neylul.kabakci@gmail.com). internal combustion engine. Energy can be harnessed from hydrogen either via a hydrogen-fuelled internal combustion engine or via fuel cells. The latter is more preferable when compared to the former due to issues related to practicability and safety [4]. It is believed that the leading types of automobiles in the $21^{\text {st }}$ century are likely to be of the following four types: internal combustion engine vehicles (ICEVs), hybrid electric vehicles (HEVs), electric vehicles (EVs), and fuel cell vehicles (FCVs) [5].

In this study, one example of an ICEV, one example of an $\mathrm{HEV}$, one example of an EV and one example of a FCV were compared and ranked by using a multi-criteria decision making method named TOPSIS (technique for preference by similarity to the ideal solution). All the selected vehicles have similar sizes and characteristics and are the registered trademarks of global automotive companies. The comparison criteria were the initial cost, operating cost, environmental effects, on-board safety and performance. The weights required for the analysis were obtained by conducting a simple survey to a total of 151 people of different economic backgrounds. Detailed explanation of the methodology can be found in the subsequent sections.

\section{TECHNOLOGY}

In this section, the basic information on four automobile power source technologies compared in the paper is given. The scores for each of the decision criteria, which will be presented in Section IV, are relevant to the information mentioned here; however numerical data will not be provided in this section.

\section{A. Internal Combustion Engine Vehicles (ICEVs)}

An ICEV is a vehicle in which primary motive power is derived from an engine that converts fuel energy to work using the air-fuel mixture as the working fluid [6]. Internal combustion engine is the oldest and the most common technology in the automotive industry. The basic components of an ICEV are the fuel tank, the engine itself and transmission equipment. The most common fuels used in ICEVs are gasoline and diesel. Gasoline-fuelled systems rely on spark ignition technology whereas diesel-fueled systems rely on compression ignition technology. The simple operation mechanism of an ICEV is shown in Fig. 1 below.

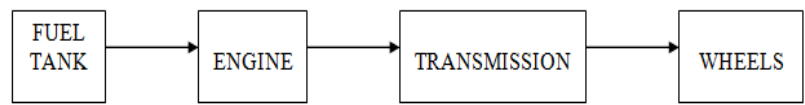

Fig. 1. Basic operation mechanism of an internal combustion engine vehicle

ICEVs have much lower initial costs when compared to 
other alternatives because internal combustion engine technology is very well-developed. Gasoline and diesel are abundant fuels, however one major disadvantage of ICEVs is the low energy-yield efficiency of the process of fuel combustion. In spark ignition technology, for instance, approximately $20-25 \%$ of the fuel energy can be converted into useful work, which implies that the relative cost per distance traveled is much higher than the relative cost of fuel on a mass or volumetric basis, when compared to other technologies [7]. Furthermore, ICEVs bear the hazards of GHG emissions and emissions of air pollutants, as stated in Section I. To minimize such emissions, additional equipment such as catalytic converters must be included in the design, leading to an increase in the cost and also the weight, thereby affecting the vehicle performance. Safety is also a concern, as ICEV fuels are flammable by nature and any leak during an accident is a fire hazard. Furthermore, the high temperatures attained inside the engine during the operation also is a cause of danger in case of a malfunction. When you submit your final version, after your paper has been accepted, prepare it in two-column format, including figures and tables.

\section{B. Electric Vehicles (EVs)}

An electric vehicle is one that utilizes a battery as the only power source. Their main advantage is the reduced environmental effect, as the tailpipe (direct) GHG emissions caused by EVs are zero. However, depending on how the electricity which is used to power the motor is generated, a certain amount of indirect GHG emissions and/or air pollutant emissions would be inevitable. Currently, the initial cost of EVs is relatively high, mainly because of the high costs of the batteries [2], [8], [9]. EVs are also disadvantaged from a performance point of view when compared to ICEVs because with the current battery technologies, the top speeds and driving ranges are limited. However, EVs have much lower operating costs than those of ICEVs. Tie et al. state that the approximate cost-to-distance ratio of EVs is one-sixth of that of ICEVs [10]. The simple operation mechanism of an EV is shown in Fig. 2 below.

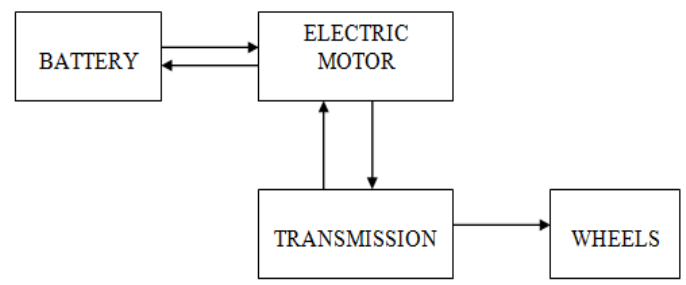

Fig. 2. Basic operation mechanism of an electric vehicle.

\section{Hybrid Electric Vehicles (HEVs)}

Hybrid electric vehicles have also gained significant popularity recently, mainly due to environmental concerns. HEVs contain an internal combustion engine coupled with an electric motor. There are two different HEV designs. In the parallel configuration (see Fig. 3a below), which is also called the "plug-in-hybrid vehicle", the battery pack and the internal combustion engine are independent from each other, and the power requirement of the vehicle is met by these two sources via a complex controller to get the optimum power output. In the series configuration (see Fig. $3 \mathrm{~b}$ below), the internal combustion engine is the main source of power, and a generator produces electricity for the electric motor, which then operates in conjunction with the internal combustion engine to get the optimum power output. HEVs are promising alternatives for future road transport, as the typical battery packs in HEVs are smaller than those in EVs, which makes HEVs cheaper and lighter. Furthermore, their well-to-wheels efficiencies are usually higher than those of fuel cell vehicles [11]-[14]. The simple operation mechanisms of both series and parallel HEVs are shown in Fig. 3 below.

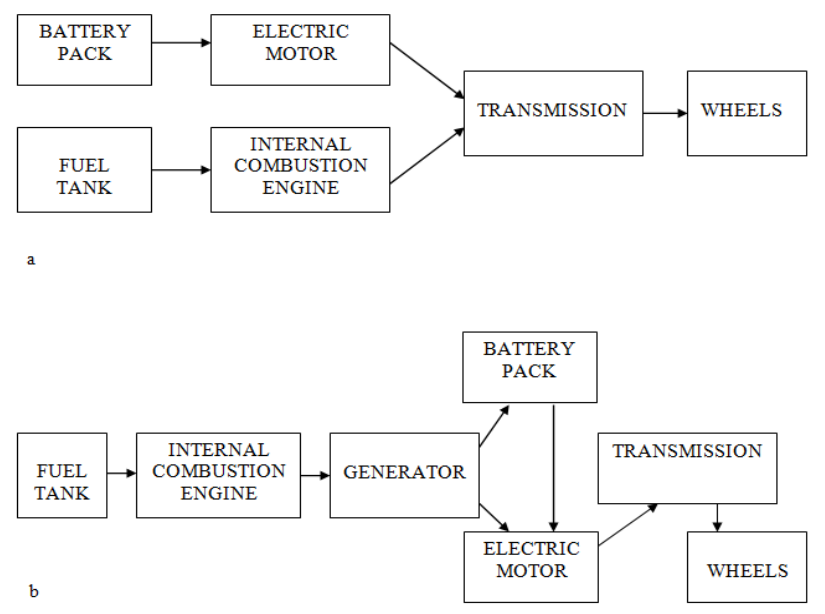

Fig. 3. Basic operation mechanism of a hybrid electric vehicle (a) parallel drivetrain (b) series drivetrain.

\section{Fuel Cell Vehicles (FCVs)}

FCVs are a more recently-emerged technology, but the possibility of clean and silent operation, and the high efficiency of hydrogen (H2) as a fuel make FCVs a promising candidate as far as future transportation is concerned. However, the lack of infrastructure for the supply of hydrogen and the problems associated with the on-board storage of hydrogen hinder the commercialization of FCVs for the time being. Out of many fuel cell types, proton exchange membrane fuel cells (PEMFCs) emerge as the ideal one for vehicular applications mostly because of their compactness, as the electrolyte in this type of fuel cells is a solid membrane. High power density and low operation temperature of PEMFCs are also influential on this selection [15]-[17]. The simple operation mechanism of an FCV is shown in Fig. 4 below.

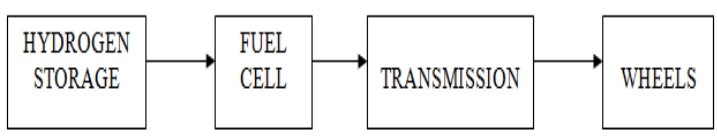

Fig. 4. Basic operation mechanism of a fuel cell vehicle

\section{Multi-CRiteria Decision MaKing Methodology}

Multiple-criteria decision making (MCDM) or Multiple-criteria decision analysis (MCDA) is a sub-discipline of operations research that deals with creating mathematical and computational tools to realize the subjective evaluation of a finite number of decision alternatives with respect to a finite number of performance criteria. MCDA/MCDM combines know-how from many 
fields, such as mathematics, behavioral decision theory, economics, computer technology, software engineering and information systems. MCDA/MCDM has become a popular research area recently, leading to the publishing of several books or scientific articles on this particular topic. MCDA/MCDM methods have been created and implemented to designate a preferred alternative, classify alternatives in a small number of categories, and rank alternatives in a subjective preference order [18]-[21].

Among various MCDA/MCDM methods developed to solve real-world decision problems, Technique for Order Preference by Similarity to Ideal Solution (TOPSIS) is a versatile method that can be successfully applied in a great number of areas. Hwang and Yoon originally proposed TOPSIS in 1981 to help select the best alternative with a finite number of criteria [19]. As a well-known classical MCDA/MCDM method, TOPSIS has gained considerable popularity amongst researchers and practitioners from different backgrounds.

\section{A. Principles of TOPSIS}

TOPSIS is a conceptually simple ranking method, which is also quite easy to apply. The main principle of the standard TOPSIS method is based on choosing alternatives that simultaneously have the shortest distance from the positive ideal solution and the farthest distance from the negative-ideal (nadir) solution. In the positive ideal solution, the benefit criteria are maximized and the cost criteria are minimized, whereas in the negative ideal solution the cost criteria are maximized and the benefit criteria are minimized. TOPSIS uses the attribute information to the full extent, ranks the alternatives, and does not require attribute preferences to be independent. To apply this technique, attribute values must be numerical, monotonically increasing or decreasing, and have commensurable units [18].

The TOPSIS method involves six steps. These steps are given below [22]:

1) Calculate the normalized decision matrix. The normalized value $r_{\mathrm{ij}}$ is calculated as follows:

$$
r_{i j}=f_{i j} / \sqrt{\sum_{j=1}^{J} f_{i j}^{2}}, j=1,2, \ldots, J ; i=1,2, \ldots, n
$$

where $J$ is the number of alternatives, $n$ is the number of criteria and $f_{i j}$ is the evaluation value of the $i^{\text {th }}$ criterion for alternative $a_{i}$.

2) Calculate the weighted normalized decision matrix. The weighted normalized value $v_{i j}$ is calculated as follows:

$$
v_{i j}=w_{i} r_{i j}, j=1,2, \ldots, J ; i=1,2, \ldots, n
$$

where $w_{i}$ is the weight of the $i^{\text {th }}$ attribute or criterion and

$$
\sum_{i=1}^{n} w_{i}=1
$$

3) Determine the ideal and negative-ideal solution

$$
\begin{aligned}
& A^{*}=v_{1}^{*}, \ldots, v_{n}^{*}=\left(\max _{j} v_{i j} \perp i \in I^{\prime}\right),\left(\min _{j} v_{i j} \perp i \in I^{\prime \prime}\right) \\
& A^{-}=v_{1}^{-}, \ldots, v_{n}^{-}=\left(\min _{j} v_{i j} \perp i \in I^{\prime}\right),\left(\max _{j} v_{i j} \perp i \in I^{\prime \prime}\right)
\end{aligned}
$$

where $I^{\prime}$ is associated with the benefit criteria and $I^{\prime \prime}$ is associated with the cost criteria.

4) Calculate the separation measures, using the n-dimensional Euclidean distance. The separation of each alternative from the ideal solution is given as:

$$
D_{j}^{-}=\sqrt{\sum_{i=1}^{n}\left(v_{i j}-v_{i}^{-}\right)^{2}}, j=1,2, \ldots, J
$$

5) Calculate the relative closeness to the ideal solution. The relative closeness of the alternative $a_{j}$ with respect to $A^{*}$ is defined as:

$$
C_{j}^{*}=D_{j}^{-} /\left(D_{j}^{*}+D_{j}^{-}\right), j=1,2, \ldots, J
$$

6) Rank the preference order.

The TOPSIS method has certain advantages. First of all, it is a relatively simple and fast method. It can be used for the comparison of an infinite number of alternatives by considering an infinite number of criteria (or attributes). While selecting the optimum alternative, the effect of each attribute cannot be evaluated alone and must always be seen as a trade-off with respect to other attributes. In other words, changes in one attribute can be compensated for in a direct or opposite manner by other attributes [21]. One significant advantage of the TOPSIS method over other MCDM methods is that the output can be a preferential ranking of the alternatives with a numerical value that provides a clearer understanding of differences and similarities between alternatives, whereas other MCDM techniques such as the ELECTRE method [23] only determine the rank of each alternative. Furthermore, TOPSIS does not require pair-wise comparisons as in the case of Analytical Hierarchy Processes (AHP) [24]. This is especially useful when working with a large number of alternatives and criteria.

Although the TOPSIS method has a great number of advantages, there also exist some disadvantages. For instance, the TOPSIS method uses the Euclidean distance algorithm in principle, but the algorithm does not take the correlation of the attributes into account and the weight coefficients are usually determined either by using expert investigation methods or by the AHP method, both of which are subjective by nature. It gets more difficult to determine the weights and keep the consistency of the judgment matrix at the same time, especially when the number of attributes increases [25].

There are many studies in the literature where TOPSIS method has been used to deal with an energy systems-related comparison or ranking problem [18], [20], [21], [26]-[33]. However, application of multi-criteria decision making methods in general, and not only TOPSIS in particular, in the field comparing various energy technologies for automobiles is not common. Vahdani et al. [34] used two novel fuzzy MCDM methods to compare alternative buses such as electric 
buses or fuel cell-powered buses. Their comparison was based on several criteria such as energy efficiency, environmental effects, cost, vehicle capability and passenger comfort. Tzeng et al. [5] used TOPSIS and VIKOR methods to compare hybrid electric buses, fuel cell (hydrogen) buses and methanol-fuelled buses for possible public transportation options in Taiwan. Their decision criteria were exactly as same as those selected by Vahdani et al. Similar to our study, Tzeng et al. also referred to the opinions of several subject groups, such as experts in the automotive industry or academicians in order to obtain the weight distributions. Although this particular study displays significant resemblances to ours, there is one major difference. The weight distributions for the criteria that are taken into account for large-scale public transportation is quite different than those for passenger vehicles. For instance, vehicle capability, which is not one the evaluation criteria in our study, was chosen as the most important criterion by the three out of five subject groups in the study of Tzeng et al. Hence, despite the similarity of the methods, our results and the results obtained by Tzeng et al. turned out to be completely unlike. And finally, Streimikiene et al. [35] employed TOPSIS method in order to assess energy technologies in road transport sector in terms of atmospheric emissions and costs. While having common features with our study, the work of Streimikine et al. differs from ours in the sense that the evaluation criteria are limited to atmospheric emissions and costs only. Furthermore, the weight vectors were created subjectively by the authors.

This particular study does not aim at developing a new method or modifying any existing method. Instead, we are interested in comparing and ranking various power source technologies utilized in automobiles by using a numerical and reproducible, thus scientific, approach. While we are aware that this particular paper does not introduce a novel methodology aside from the fact that we obtained our weight distributions via a questionnaire, the application of MCDM approach in the form of the TOPSIS method in the field of comparing power sources for passenger automobile transmission systems has not been realized previously and this, in our opinion, is the justification for the originality of the work.

\section{B. Selection of Evaluation Criteria}

Before selecting the evaluation criteria, the automobiles that would be compared had to be chosen. As indicated before, it does not matter what size the automobiles are, as long as the sizes are comparable. Thus, for EVs, Ford Focus ElectricTM; for HEVs, Toyota Prius CTM; for ICEVs, Toyota YarisTM and for HFCVs, Honda FCX ClarityTM had been chosen. All four of these automobiles are 4-door models, with passenger volumes ranging between 85 and $90 \mathrm{ft} 3$. Hence, it was concluded that these automobiles were similar enough to be compared.

There are many different criteria that consumers take into account while deciding on which automobile to purchase. Amongst the first ones that would come to mind is the cost. However, the initial cost and operating cost have to be considered separately. It is a well-known fact that automobiles with better fuel economy might have higher turn-key prices. Thus, two separate price criteria were defined: the vehicle price (initial cost in US dollars) and the external price (operating cost in US dollars). The definition of external price in this study was "the cost of driving 25 miles at typical speeds".

Another important criterion is the performance. However, performance is a vague term and in this particular study, all criteria must be as measurable as possible. Thus, it was decided to define performance as the maximum speed of the automobile $(\mathrm{km} / \mathrm{h})$. As far as conventional ICEVs are concerned, most brands manufacture automobiles with similar maximum speeds and therefore the maximum speed is not a common comparison criterion, with the exception of sports vehicles. However, with EVs, HEVs and FCVs in the picture, it would be reasonable to consider maximum speed as an indicator of performance, as the maximum speed of these different vehicle types are usually not very close to each other due to current technological limitations.

Safety is also an important criterion, one that many consumers give priority to. Hence, we decided to include safety as one of the evaluation criteria. However, typical safety scores of automobiles are based on their crash test results, and crash test results are usually determined by how safe the design is and normally would not be affected by the type of the power source within the automobile. Since the aim of this study is to compare the power sources, it was essential to relate the safety scores to the type of the power source. Therefore, we considered the secondary risks associated with the power source in case of a failure. For instance, hydrogen in FCVs or liquid fuels in ICEVs and HEVs are flammable and bear the risk of fire in case of a malfunction. Also, as both these fuels are in fluid phase under the operating conditions, leakage is also a possible hazard. Furthermore, the temperatures inside internal combustion engines easily reach extreme values during the operation of the engine, which in turn also puts the driver in risk in case of a malfunction. This was the approach we followed while determining the safety scores for each automobile type. While we are aware that determining the safety scores subjectively as we did via this particular approach contradicts with our earlier statement regarding "selecting measurable criteria", we simply decided that safety is a very crucial criterion that cannot be overlooked and even without available numerical data, it was absolutely essential to evaluate the power source types in terms of safety.

Last but not least, the environmental effects of each automobile type were compared. The scores were based on lifecycle greenhouse gas emissions (109 tons CO2-equivalent per year) and were obtained from the available literature.

\section{Determination of the Weights}

Weight determination is subjective by nature; however we decided to determine the weights by performing a survey on people of different economic backgrounds, so that the weight values would not simply be decided by ourselves. The survey was kept quite simple. The subjects were asked to list the five decision criteria (vehicle price, external price, performance, safety, and environmental effect) in descending order, with the most important criterion receiving a grade of 5 and the least important one receiving a grade of 1 . Afterwards, the average grade of each criterion was calculated and then the average grades were normalized, while limiting their sum to 
unity. The weight determination method can be formulated as follows:

$$
a_{\text {sum }}=\sum_{i=1}^{n} a_{i}
$$

where $a_{\text {sum }}$ is the total grade of criterion $a, a_{i}$ is the grade of criterion a given by the subject $\mathrm{i}$ and $\mathrm{n}$ is the total number of the subjects within the weight determination group. The average grade of each criterion was then determined as follows:

$$
a_{\text {avg }}=\frac{a_{\text {sum }}}{n}
$$

where $a_{a v g}$ is the average grade of criterion a. As indicated above, there are a total of five criteria and for the sake of simplicity, it was assumed that the remaining criteria are symbolized by letters $b, c, d$, and $e$, respectively. The normalized average grades were then calculated as follows:

$$
a_{n o r m}=\frac{a_{a v g}}{\min \left(a_{a v g}, b_{a v g}, c_{a v g}, d_{a v g}, e_{a v g}\right)}
$$

where $a_{\text {norm }}$ is the normalized average grade of criterion a. With this approach, the minimum normalized grade value would be 1 , and the remaining ones would be greater than 1 . The final step for the determination of each individual weight value can be found below:

$$
w_{a}=\frac{a_{\text {norm }}}{a_{\text {norm }}+b_{\text {norm }}+c_{\text {norm }}+d_{\text {norm }}+e_{\text {norm }}}
$$

where $w_{a}$ is the weight of criterion $a$.

In this study, three different subject groups were formed, classified according to the monthly income of the subjects. Group 1 (70 people) consisted of subjects with monthly incomes less than 5,000 TRY, while group 2 (35 people) consisted of subjects with monthly incomes between 5,000 and 10,000 TRY, and finally Group 3 (26 people) consisted of subjects with monthly incomes greater than 10,000 TRY. Since most of the selected attributes (or criteria) are related to financial capability of the subjects, we thought different income groups could have different tendencies. The survey was performed online and it had remained active for a period of 60 days.

\section{RESUlTS AND DISCUSSION}

Before proceeding with the ranking of automobile types, the evaluation criteria scores and weight values need to be presented.

\section{A. Evaluation Criteria Scores}

In Table I below, the scores of each automobile type for the criteria mentioned above are presented. Since it is quite difficult to gather such compilations in an up-to-date manner from books or scientific articles, internet websites were mainly used as reference during the preparation of Table I.

TABLE I: EvaluATION CRITERIA SCORES OF EACH AUTOMOBILE TYPE

\begin{tabular}{lcccc}
\hline \multicolumn{5}{c}{ [36]-[47] } \\
\hline Criteria & $\begin{array}{l}\text { EV } \\
\text { Ford } \\
\text { FocusTM }\end{array}$ & $\begin{array}{l}\text { HEV } \\
\text { Toyota } \\
\text { PriusTM }\end{array}$ & $\begin{array}{l}\text { ICEV } \\
\text { Toyota } \\
\text { YarisTM }\end{array}$ & $\begin{array}{l}\text { FCV } \\
\text { Honda } \\
\text { FCX } \\
\text { ClarityTM }\end{array}$ \\
\hline Vehicle Price (\$) & 39,200 & 21,220 & 15,825 & 72,000 \\
\hline $\begin{array}{l}\text { External Price } \\
(\$ / 25 \text { miles) }\end{array}$ & 0.96 & 1.77 & 2.73 & 1.68 \\
\hline $\begin{array}{l}\text { Environmental } \\
\text { Effects (10 } \text { tons } \\
\text { CO2 } \\
\text { equivalent/year) }\end{array}$ & 1.5 & 1.5 & 1.6 & 1.45 \\
\hline Safety & 1 & 0.9 & 0.9 & 0.7 \\
\hline $\begin{array}{l}\text { Performance } \\
(\mathrm{km} / \mathrm{h})\end{array}$ & 135 & 169 & 171 & 160 \\
\hline
\end{tabular}

As indicated above, the safety scores were determined subjectively due to a lack of measurable data. We considered FCVs to be the least safe type as hydrogen is highly flammable and explosive. Since both ICEVs and HEVs contain a fuel tank filled with flammable liquid fuel, we also considered them to be less safe than EVs, but safer than FCVs. Hence, EVs were given a safety score of 1 , ICEVs and HEVs were given safety scores of 0.9 and FCVs were given a safety score of 0.7 . Although there is no reference study to back up our decision for the determination of the above-mentioned normalized safety scores, there are studies in which the order of these technologies from the safest towards the least safe are consistent with our choice [48], [49].

In order to be used in TOPSIS, the scores must be given in a normalized manner since the orders of magnitude differ immensely from criterion to criterion. However, this proved to be a challenge due to one particular reason: Certain criteria approach the ideal case when the scores increase in magnitude (like performance or safety) while the rest approach the nadir case when the scores increase in magnitude (like prices and environmental effects). To overcome this complexity, each criterion was handled individually. For the criteria of performance and safety, a normalized score of 1 was given to the automobile type with the highest score. For the remaining criteria, however, a normalized score of 1 was given to the automobile type with the lowest score and the rest of the normalized scores were calculated by proportioning.

In Table II below, the normalized scores of each automobile type for the criteria mentioned above are presented.

TABLE II: NORMALIZED EVALUATION CRITERIA SCORES OF EACH

\begin{tabular}{lllll}
\multicolumn{5}{c}{ AUTOMOBILE TYPE } \\
\hline Criteria & $\begin{array}{l}\text { EV } \\
\text { Ford } \\
\text { Focus }^{\mathrm{TM}}\end{array}$ & $\begin{array}{l}\text { HEV } \\
\text { Toyota } \\
\text { Prius }^{\mathrm{TM}}\end{array}$ & $\begin{array}{l}\text { ICEV } \\
\text { Toyota } \\
\text { Yaris }^{\mathrm{TM}}\end{array}$ & $\begin{array}{l}\text { FCV } \\
\text { Honda FCX } \\
\text { Clarity }^{\mathrm{TM}}\end{array}$ \\
\hline Vehicle Price & 0.40 & 0.75 & 1 & 0.22 \\
$\begin{array}{l}\text { External Price } \\
\text { Environmental }\end{array}$ & 1 & 0.54 & 0.35 & 0.57 \\
$\begin{array}{l}\text { Effects } \\
\text { Safety }\end{array}$ & 0.97 & 0.97 & 0.91 & 1 \\
Performance & 0.79 & 0.99 & 1 & 0.7 \\
\hline
\end{tabular}




\section{B. Weight Values}

The weight values, calculated as described in Section III.C, can be found in Table III below.

TABLE III: WEIGHT VALUES FOR THREE SUBJECT GROUPS

\begin{tabular}{lllllll}
\hline & VP & EP & EE & S & P & $\Sigma$ \\
\hline $\begin{array}{l}\text { Subject } \\
\text { Group 1 } \\
\text { (income }<\end{array}$ & 0.233 & 0.228 & 0.157 & 0.233 & 0.152 & 1 \\
$\begin{array}{l}5,000 \text { TRY) } \\
\text { Subject }\end{array}$ & & & & & & \\
$\begin{array}{l}\text { Group 2 } \\
\text { (income }>\end{array}$ & & & & & & \\
$\begin{array}{l}5,000 \text { TRY) } \\
\text { (income }<\end{array}$ & 0.222 & 0.203 & 0.179 & 0.218 & 0.177 & 1 \\
$\begin{array}{l}10,000 \\
\text { TRY) }\end{array}$ & & & & & & \\
$\begin{array}{l}\text { Subject } \\
\text { Group 3 } \\
\text { (income }>10\end{array}$ & 0.230 & 0.198 & 0.170 & 0.214 & 0.189 & 1 \\
,000 TRY) & & & & & & \\
\hline
\end{tabular}

In the table above, $V P$ stands for "vehicle price", $E P$ stands for "external price", $E E$ stands for "environmental effect", $S$ stands for "safety", $P$ stands for "performance", and $\Sigma$ stands for sum, respectively. As we analyze the weight distributions, it is obvious that the vehicle price is the most important criterion according to the subjects in our survey, as two of the three subject groups gave the "vehicle price" criterion the highest grade and the "safety" criterion the second highest grade. It was very interesting to see that the "safety" criterion was chosen to be the most important criterion amongst the first subject group and the second most important criterion amongst the second and the third subject group. This shows that safety must be added as a criterion in this type of analyses and justifies our reasoning regarding the subjective evaluation of safety in Section III.B. Last but not least, the "environmental effects" criterion was selected either as the least important or the second-least important criterion by all three of the subject groups. The preference order of the criteria by our subject groups is quite consistent with those reported by Yousefi and Hadi-Vencheh [50].

\section{Ranking of Automobile Power Source Types}

By applying the TOPSIS methodology as described in Section III.A, the following relative closeness values were obtained for three different subject groups, as presented in Table IV below:

TABLE IV: RESUlTS OF THE TOPSIS ANALYSIS (RELATIVE ClOSENESS VALUES)

\begin{tabular}{lccc}
\hline & Subject Group 1 & Subject Group 2 & Subject Group 3 \\
\hline ICEV & 0.531 & 0.544 & 0.559 \\
HEV & 0.528 & 0.539 & 0.549 \\
EV & 0.521 & 0.495 & 0.483 \\
HFCV & 0.339 & 0.344 & 0.345 \\
\hline
\end{tabular}

As expected, internal combustion engine vehicles emerged as the most desirable type for all three of the subject groups. The low initial costs and low operating costs of ICEVs were the key factors as two out of three subject groups selected the initial cost as the most important criterion whereas in all three subject groups, the operating cost was selected as the third most important criterion. Hydrogen fuel cell vehicles emerged as the least desirable type for all three subject groups. This finding was also an anticipated one since HFCVs received the lowest normalized scores for four criteria out of five. HFCV technology is currently premature when compared to the others, and consequently the initial costs of such vehicles are very high. Although hydrogen fuel cells are more efficient than the rest of the power sources investigated in this study from a power density point of view, the lack of an infrastructure for the wide-spread production and distribution of hydrogen as well as the risks associated with carrying a not only flammable but also explosive gas on board meant that HFCVs for the time being are not realistic competitors to ICEVs, EVs or HEVs in the automotive industry.

One important finding of our study was to see that according to the consumer evaluations, hybrid electric vehicles are almost as desirable as internal combustion engine vehicles. For all three subject groups, HEVs emerged as the second most desirable type, with the percentage difference between the relative closeness values of ICEVs and HEVs being less than $3 \%$ in all three cases. Our results are quite consistent with the findings of van Vliet et al. [1], who recommended plug-in-hybrid vehicles as prospective alternatives to internal combustion engine vehicles. However, in their study van Vliet et al. analyzed each criterion exclusively but did not follow an integrative multi-criteria decision making approach like the TOPSIS method, in which the cumulative effects of all criteria are taken into account. As the technology develops, problems associated with the high cost, low performance or the short driving range are expected to be gradually solved and our study shows that the dominance of ICEVs in the automotive market is likely to be heavily challenged.

\section{CONCLUSION}

In this study, internal combustion engine vehicles, electric vehicles, hybrid electric vehicles and fuel cell vehicles were compared via a multi-criteria decision making method named TOPSIS. The decision criteria were the vehicle price, operating cost (cost of 25 miles of driving), environmental effects (109 tons $\mathrm{CO}_{2}$-equivalent per year), safety and performance (maximum speed). The weights of these criteria were determined by conducting a simple survey to a total of 151 people, who were then classified into three groups according to their monthly incomes. The scores for all the criteria except safety were determined objectively, while the safety scores were determined by the authors. The compared automobiles were as follows: for EVs, Ford Focus ElectricTM; for HEVs, Toyota Prius CTM; for ICEVs, Toyota YarisTM and for HFCVs, Honda FCX ClarityTM.

The results of our analysis showed that according to all three of our subject groups, internal combustion engine vehicles are the most desirable type whereas hydrogen fuel cell vehicles are the least desirable type. These results were attributed to the low initial costs and operating costs of ICEVs whereas HFCVs were out of favor due to high cost and low level of safety. Hybrid electric vehicles emerged as the closest challengers to ICEVs in the automotive industry. 
Last but not least, we would like to emphasize the points that need to be further looked into so that the quality of this particular study can be improved. First of all, the study could have been extended to take additional criteria such as durability into account, however due to the fact that HEVs, EVs and FCVs are relatively new in the market, it was concluded that reliable data on their durability would not be available. Range is another decisive factor, however with the current lack of infrastructure for hydrogen fuelling or electrical power charging stations on intercity roads, we considered it would be wiser to take into account only urban use for our comparison, thereby decreasing the importance of range as an attribute. And finally, our scientific approach can be strengthened by coming up with a measurable score for the safety criterion.

\section{REFERENCES}

[1] O. P. R van Vliet, T. Kruithof, W. C. Turkenburg, and A. P. C. Faaij, "Techno-economic comparison of series hybrid, plug-in hybrid, fuel cell and regular cars," Journal of Power Sources, vol. 195, pp. 6570-6585, October 2010.

[2] R. Schmidt, "Information technology energy usage and our planet," in Proc. 2008 ITHERM Conf., 2008, pp. 1255-1275.

[3] B. Johnston, M. C. Mayo, and A. Khare, "Hydrogen: The energy source for the 21 st century," Technovation, vol. 25, pp. 569-585, June 2005.

[4] S. Verhelst and T. Wallner, "Hydrogen-fueled internal combustion engines," Progress in Energy and Combustion Science, vol. 35, pp. 490-527, December 2009.

[5] G. H. Tzeng, C. W. Lina, and S. Opricovic, "Multi-criteria analysis of alternative-fuel buses for public transportation," Energy Policy, vol. 33 , pp. 1373-1383, July 2005.

[6] K. G. Duleep, "Internal combustion engine vehicles," Encyclopedia of Energy, vol. 3, 2004.

[7] A. M. K. P. Taylor, "Science review of internal combustion engines," Energy Policy, vol. 36, pp. 4657-4667, December 2008.

[8] O. van Vielet, A. S. Brouwer, T. Kuramochi, M. van den Broek, and A. Faaij, "Energy use, cost and CO2 emissions of electric cars," Journal of Power Sources, vol. 196, pp. 2298-2310, February 2011.

[9] C. Silva, M. Ross, and T. Farias, "Evaluation of energy consumption, emissions and cost of plug-in hybrid vehicles," Energy Conversion and Management, vol. 50, pp. 1635-1643, July 2009.

[10] S. F. Tie and C. W. Tan, "A review of energy sources and energy management system in electric vehioicles," Renewable and Sustainable Energy Reviews, vol. 20, pp. 82-102, April 2013.

[11] T. Katrasnik, "Analytical framework for analyzing the energy conversion efficiency of different hybrid electric vehicle topologies," Energy Conversion and Management, vol. 50, pp. 1924-1938, August 2009.

[12] S. M. Lukic and A. Emadi, "Effect of drivetrain hybridization on fuel economy and dynamic performance of parallel hybrid electric vehicles," IEEE Trans on Vehicular Technology, vol. 53, pp. 385-389, March 2004.

[13] H. Lee and H. Kim, "Improvement in fuel economy for a parallel hybrid electric vehicle by continuously variable transmission ratio control," in Proc. the Institution of Mechanical Engineers, Part D: Journal of Automobile Engineering, 2005, vol. 219, pp. 43-51.

[14] S. S. Williamson and A. Emadi, "Comparative assessment of hybrid electric and fuel cell vehicles based on comprehensive well-to- wheels efficiency analysis," IEEE Trans on Vehicular Technology, vol. 54, pp 856-862, May 2005.

[15] J. J. Hwang, "Sustainability study of hydrogen pathways for fuel cell vehicle applications," Renewable and Sustainable Energy Reviews, vol. 19, pp. 220-229, March 2013.

[16] J. J. Hwang, J. K. Kuo, W. Wu, W. R. Chang, C. H. Lin, and S. E. Wang, "Lifecycle performance assessment of fuel cell/battery electric vehicles," International Journal of Hydrogen Energy, vol. 38, pp. 3433-3446, March 2013.

[17] L. Barelli, G. Bidini, and A. Ottaviano, "Optimization of a PEMFC/battery pack power system for a bus application," Applied Energy, vol. 97, pp. 777-784, September 2012.
[18] M. Behzadian, S. K. Otaghsara, M. Yazdani, and J. Ignatius, "A state-of the-art survey of TOPSIS applications," Expert Systems with Applications, vol. 39, pp. 13051-13069, December 2012.

[19] C. L. Hwang and K. P. Yoon, Multiple Attribute Decision Making: Methods and Applications, New York: Springer-Verlag, 1981.

[20] K. Sadeghzadeh and M. B. Salehi, "Mathematical analysis of fuel cell strategic technologies development solutions in the automotive industry by the TOPSIS multi-criteria decision making method," International Journal of Hydrogen Energy, vol. 36, pp. 13272-13280, October 2011.

[21] A. Shanian and O. Savadogo, "TOPSIS multiple-criteria decision support analysis for material selection of metallic bipolar plates for polymer electrolyte fuel cell," Journal of Power Sources, vol. 159, pp. 1095-1104, September 2006.

[22] M. Wu and Z. Liu, "The supplier selection application based on two methods: VIKOR algorithm with entropy method and Fuzzy TOPSIS with vague sets method," International Journal of Management Science and Engineering Management, vol. 6, pp. 110-116, 2011.

[23] B. Roy, "The outranking approach and the foundations of ELECTRE methods," Theory and Decision, vol. 31, pp. 49-73, July 1991.

[24] T. L. Saaty, Fundamentals of Decision Making and Priority Theory with the Analytic Hierarchy Process, USA: RWS Publication, 2000.

[25] F. Xinhong and W. Huang. (April 2013). An engineering appraisal bidding model based on improved TOPSIS method. [Online]. Available:

http://www.seiofbluemountain.com/upload/product/200910/2009glhy 13a11.pdf

[26] F. Cavallaro, "Fuzzy TOPSIS approach for assessing thermal-energy storage in concentrated solar power (CSP) systems," Applied Energy, vol. 87, pp. 496-503, February 2010.

[27] A. T. D. Perera, R. A. Attalage, K. K. C. K. Perera, and V. P. C. Dassanayake, "A hybrid tool to combine multi-objective optimization and multi-criterion decision making in designing standalone hybrid energy systems," Applied Energy, vol. 107, pp. 412-425, July 2013.

[28] J. Dong, Y. Chi, D. Zou, C. Fu, Q. Huang, and M. Ni, "Energy-environment-economy assessment of waste management systems from a life cycle perspective: Model development and case study," Applied Energy, vol. 114, pp. 400-408, February 2014.

[29] I. Chamodrakas and D. Martakos, "A utility-based fuzzy TOPSIS method for energy efficient network selection in heterogeneous wireless networks," Applied Soft Computing, vol. 11, pp. 3734-3743, June 2011.

[30] T. Kaya and C. Kahraman, "Multicriteria decision making in energy planning using a modified fuzzy TOPSIS methodology," Expert Systems with Applications, vol. 38, pp. 6577-6585, June 2011.

[31] G. Yan, Z. Ling, and Z. Dequn, "Performance Evaluation of coal enterprises energy conservation and reduction of pollutant emissions base on GRD-TOPSIS," Energy Procedia, vol. 5, pp. 535-539, 2011.

[32] T. Wang and B. C. Xin, "Thermal power plant sitting based on TOPSIS method," Procedia Engineering, vol. 15, pp. 5384-5388, 2011.

[33] D. Choudhary and R. Shankar, “An STEEP-fuzzy AHP-TOPSIS framework for evaluation and selection of thermal power plant location: A case study from India,” Energy, vol. 42, pp. 510-521, June 2012.

[34] B. Vahdani, M. Zandieh, and R. Tavakkoli-Moghaddam, "Two novel FMCDM methods for alternative-fuel buses selection," Applied Mathematical Modelling, vol. 35, pp. 1396-1412, March 2011.

[35] D. Streimikine, T. Balezentis, and L. Balezentiene, "Comparative assessment of road transport technologies," Renewable and Sustainable Energy Reviews, vol. 20, pp. 611-618, April 2013.

[36] Compare Side-by-Side. (March 28, 2013). [Online]. Available: http://www.fueleconomy.gov/feg/Find.do?action=sbs\&id=33024\&id $=33315$ \&id $=33289$ \&id $=33290$.

[37] Benefits and challenges of fuel cell vehicles. (April 14, 2013). [Online]. Available: http://www.fueleconomy.gov/feg/fcv_benefits.shtml

[38] B. Halvorson. (March 27, 2013). 2012 Ford focus safety review and crash test ratings. [Online]. Available: http://www.thecarconnection.com/review/1057345_2012-ford-focus_ safety_5.

[39] B. Halvorson. (March 27, 2013). 2013 Toyota Yaris safety review and crash test ratings. [Online]. Available: http://www.thecarconnection.com/review/1080573_2013-toyota-yaris _safety_5.

[40] J. Voelcker. (May 31, 2013). 2013 Toyota Prius safety review and crash test ratings. [Online]. Available: http://www.thecarconnection.com/review/1079583_2013-toyota-priu s_safety_5.

[41] Information on Honda FCX clarity. (May 6, 2013). [Online]. Available: http://automobiles.honda.com/fcx-clarity/. 
[42] D. Gluckman. (May 5, 2013). 2012 ford focus electric official photos and information. [Online]. Available: http://www.caranddriver.com/news/2012-ford-focus-electric-revealed -ford-focus-news.

[43] J. Gall. (May 5, 2013). Information on 2012 Toyota Prius C. [Online]. Available: http://www.caranddriver.com/reviews/2012-toyota-prius-c-first-drivereviews.

[44] S. Siler. (May 5, 2013). Information on 2012 Toyota Yaris. [Online]. Available:

http://www.caranddriver.com/reviews/2012-toyota-yaris-first-drive-re view.

[45] Honda FCX Clarity Frequently Asked Questions [Online]. Available: http://automobiles.honda.com/fcx-clarity/faq.aspx.

[46] C. E. Thomas. (October 3, 2013). Fuel cell and battery electric vehicles compared. [Online]. Available: www1.eere.energy.gov/hydrogenandfuelcells/education/pdfs/thomas_ fcev_vs_battery_evs.pdf.

[47] G. Blencoe. (October 3, 2013). Cost of hydrogen from different sources. [Online]. Available: http://www.h2carblog.com/?p=461.

[48] C. Murray. (October 3, 2013). Why electric cars are safer. [Online]. Available:http://www.designnews.com/author.asp?section_id=1366\& doc_id=267317\&dfpPParams=ind_184,industry_auto,bid_318,aid_2 $67317 \&$ dfpLayout $=$ blog.

[49] Electric cars are safer. [Online]. Available: http://hfboards.hockeysfuture.com/showthread.php?p=70989127.

[50] A. Yousefi and A. Hadi-Vencheh, "An integrated group decision making model and its evaluation by DEA for automobile industry," Expert Systems with Applications, vol. 37, pp. 8543-8556, December 2010.

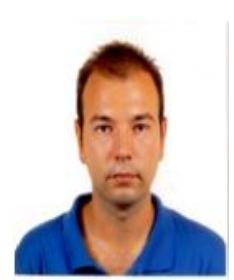

Fehmi Görkem Üçtuğ was born in Ankara, Turkey, on November $20^{\text {th }}, 1982$. He received his B.Sc. degree in chemical engineering from Middle East Technical University (Ankara, Turkey) in 2004 and his Ph.D. degree in chemical engineering from The University of Manchester (United Kingdom) in 2008. His major fields of interest are fuel cell systems, energy efficiency in buildings, engineering economics and process optimization.

He had worked as a summer intern at ASELSAN and ECZACIBAŞI PLC, in the summers of 2002 and 2003, respectively. After completing his Ph.D., he spent one year working as a chemical analysis specialist in Turkish Armed Forces before joining the Energy Systems Engineering Department of Bahçeşehir University (İstanbul-Turkey) in 2010, where he has been working as an assistant professor since. He had been promoted to the position of vice-dean of Engineering Faculty in September 2013. His current research interests are financial incentive systems for the promotion of renewable energy investments, multi-criteria decision making processes for energy-related processes, fuel cell vehicle design.
Dr. Uctug is currently a member of "International Society of Electrochemistry" and "International Association of Energy Economics". His Ph.D. study was funded by the Marie Curie Fellowship via the $6^{\text {th }}$ EU Framework Program. He is currently an organization committee member for the upcoming "Economic, Environmental, Technological and Security Challenges for Energy" conference to be held in Antalya-Turkey on 25-27 May, 2015.

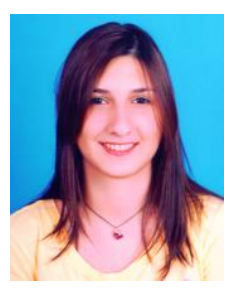

Naz Eylül Kabakcı was born in İstanbul, Turkey, on January $23^{\text {rd }}, 1991$. She received her B.Sc. degree in energy systems engineering from Bahçeşehir University (İstanbul-Turkey) in 2013. This particular paper was written based on her findings in her graduation project work, which was supervised by Asst. Prof .Dr. F. Görkem Üçtuğ.

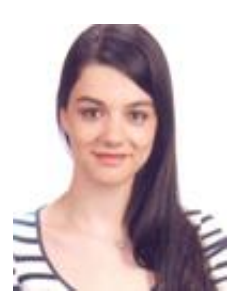

Betül Akyürek was born in Denizli, Turkey, on July 25, 1989. She received her bachelor's degrees from Energy Systems Engineering and Electrical Electronics Engineering Departments (Double Major) of Bahcesehir University, Istanbul, Turkey, in 2012. She is currently studying for an electrical engineering M.Sc. degree in Istanbul Technical University and an engineering management M.Sc. degree in Bahcesehir University. Ms. Akyürek's major fields of study are renewable energy systems, and distributed generation.

She had worked as a part time engineer in Schneider Electric between April and September 2012. She is currently a research and teaching assistant at Bahcesehir University.

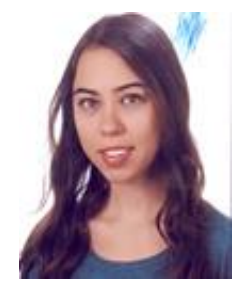

Olcay Buğu Bekdikhan was born in Antalya, Turkey, on April 9, 1991. She received her B.Sc. degree in energy systems engineering from Bahcesehir University in 2012. In the same year she started to study for an electrical and electronics engineering M.Sc. degree in Bahcesehir University. Ms. Bekdikhan's major study fields are renewable energy sources and their grid connection. Bekdikhan is currently a research and teaching assistant at 


\section{Energy-Saving Technology}


